\title{
Indian Stock market and Aggregate macroeconomic variables: Time Series Analysis
}

\author{
Mohanamani. $\mathrm{P}^{1}$, Dr. T. Sivagnanasithi ${ }^{2}$ \\ ${ }^{I}$ (Assistant Professor, KCT Business School, Kumaraguru College of Technology, Coimbatore, India) \\ ${ }^{2}$ (Assistant Professor, Department of Commerce, Chikkanna Government Arts College, Tiruppur, India)
}

\begin{abstract}
This study investigates the impact of macroeconomic variables on the behaviour of Indian Stock market. Monthly data about six macro economic variables such as BSE Sensex, Call Money rate, Exchange rate between Indian Rupees and US dollar, Foreign Institutional Investment, Industrial productivity, money supply and whole sale price index over the period 2006:04 to 2013:07 has been taken for study. Descriptive Statistics, Pearson's correlation matrix, Unit root test and Granger Causality tests have been applied to test the relationship between stock market and the above mentioned macroeconomic variables. The analysis reveals that Indian stock market is positively whole sale price index, money supply and industrial productivity. The exchange rate and inflow of foreign institutional investment are found to be insignificant to Indian Stock market. In the Granger Causality sense, whole sale price index and industrial productivity influence the stock market to a great extent.
\end{abstract}

Keywords: Macro economic variables, Indian Stock Market, Unit root tests, Granger causality test.

\section{Introduction}

Day to day happenings and news are reflected in the stock market, some of them may be relevant to the stock market as they indicate the changes in the economic and financial fundamentals while others may be irrelevant. Often stock market is viewed as "informationally efficient", negative events and "bad news" develops their impact consistently faster than positive elements and "good news". The stock market avail longterm capital to the listed firms by pooling funds from different investors and allow them to expand in business and also offers investors alternative investment avenues to put their surplus funds in, investors carefully watch the performance of stock markets by observing the composite market index, before investing funds. The market index acts as the yardstick to compare the performance of individual portfolios and also provides investors for forecasting future trends in the market. Especially the stock markets of emerging economies are likely to be sensitive to fundamental changes in economic structure and policies play an important role than the current news. The state of the Indian economy has a bearing on the share prices, but, the health of the stock markets in terms of a rising share price index is not reflective of an improvement in the health of the economy. In other words a rising indices in the stock markets cannot be taken to be a leading indicator of the revival of the economy in India and vice versa (Agrawalla, 2006). However, Shah and Thomas (1997) are of the opinion that stock prices act as a mirror which reflect the real economy. Kanakaraj et al. (2008) had also examined the trend of stock prices and various macroeconomic variables between the time periods 1997-2007 and tried to explore upon if the rise in the stock market can be explained in the terms of macroeconomic fundamentals and concluded by recommending a strong relationship between the two. The interaction of stock market indices returns and the macroeconomic variables has been a subject of intense study among researchers and practitioners. The purpose of the present study is to investigate whether there is any causal relationship persisting in India between macroeconomic variables, namely, Wholesale Price index (WPI), Index of Industrial Production (IIP), exchange rate (Rs./US\$), Call Money Rate (CMR) and Indian stock markets in the form of BSE SENSEX (B-SENSEX) by using monthly data that span from April, 2007 to March, 2012.More precisely, in this study relationship between the selected macroeconomic variables and BSE Sensex is tested by using correlation analysis, Granger Causality test. The results would be useful for the traders, policy makers, investors and academicians concerned with future research.

\section{Literature Review}

Pethe and Karnik (2000), by using Indian data attempted to find the impact of macroeconomic variables on Indian stock price indices. But, this study had run causality tests in an error correction framework on non-co integrated variables, which is inappropriate and not econometrically sound and correct. The study reported weak causality running from IIP to share price indices (i.e., SENSEX and S\&P CNX NIFTY) In other words, it holds the view that the state of economy had affected stock prices. 
Bhattacharya and Mukherjee (2006) examined the relationship between the Indian stock market and seven macroeconomic variables by employing the VAR framework and Toda and Yamamoto non-Granger causality technique for the sample period of April 1992 to March 2001. Their study indicated that there was no causal linkage between stock returns and money supply, index of industrial production, GNP, real effective exchange rate, foreign exchange reserve and trade balance. However, they found a bi-directional causality between stock return and rate of inflation over the study period.

Gay (2008) analyzed the association between stock prices and macroeconomic variables among China, India, Brazil and Russia which are emerging economies of the world by using oil price, exchange rate, and moving average lags values as explanatory variables with OLS (Ordinary Least Square) and found insignificant results. And finally concluded that in emerging economies the domestic factors influence more than external factors namely exchange rate and oil prices.

Rahman and Uddin (2009) examined the relationship between exchange rates and stock prices of three emerging countries of South Asia named as Bangladesh, India and Pakistan. They took average monthly nominal exchange rates of US Dollar in terms of Bangladeshi Taka, Indian Rupee and Pakistani Rupee and monthly values of Dhaka Stock Exchange General Index, Bombay Stock Exchange Index and Karachi Stock Exchange and all Share Price Index for period of January 2003 to June 2008 for the purpose of the study and found there was no co-integrating relationship between stock prices and exchange rates. They also applied Granger causality test which showed there is no casual relationship between stock prices and exchange rates in chosen countries for the study period.

Yadav and Lagesh (2011) studied the dynamic interrelations among the macroeconomic variables of real output, money, price, interest rate and exchange rate using monthly data for India covering the period from 1991:1 to 2007:12 .The bounds test revealed that there existed a long-run relation between real output, money supply, interest rate and exchange rate when the price variable was the dependent variable. Also, a long-run relationship between real output, money supply, price and interest rate was found when exchange rate was the dependent variable. The short-run causality found no evidence between real output and money and a unidirectional causality running from price and interest rate to real output was found. Finally, it was found that output, money, price and interest rate had no effect on exchange rate in the short-run.

As discussed above, existing literature reveals differential causal patterns and relationships between key macroeconomic variables and Indian stock markets. These relationships tend to vary in a number of different stock markets and time horizons in the literature throughout the world as well as in Indian context.

\section{Objectives of the study}

To analyze whether macroeconomic variables chosen for study have impact on the Indian Capital Market

\subsection{Data}

\section{Data, Variables and Methodology}

In this study monthly data from April, 2007 to March, 2012 was taken to examine the relationships between the selected macroeconomic variables and BSE SENSEX (used as a proxy to Indian stock markets) Index and other macroeconomic variables, i.e., the Wholesale Price Index (used as a proxy to domestic inflation), the Index of Industrial Production (used as a proxy to Indian GDP), Indian Rupee to US Dollar (used as a proxy to India's foreign exchange rate), and Call Money Rate (used as a proxy to domestic interest rate) were used in this study. The data were obtained from Annual Reports of BSE, monthly bulletins of Securities and Exchange Board of India (SEBI) and Reserve Bank of India (RBI).

\subsection{Variables}

\subsubsection{BSE SENSEX}

Even though the BSE was established in 1875, till the decade of 1980s there was no scale to measure the ups and downs in the Indian stock markets. In 1986, the BSE came out with a stock index (i.e., the SENSEX) that subsequently became the barometer of the Indian stock markets. Also, due to its wide acceptance amongst the Indian investors and the Foreign Institutional Investors, BSE SENSEX is regarded to be the pulse of Indian stock markets. As the oldest Index in the country, it provides the time series data over a fairly long period of time right from 1979 onwards. It is a value weighted stock average, using the free float market capitalization methodology, of 30 largest and most actively traded stocks of Indian stock markets from varied sectors being the most quoted Index. Thus, BSE-SENSEX has been selected for this study as the representative of Indian stock market. 


\subsubsection{Wholesale Price Index (WPI)}

Inflation is an increase in the general level of prices, or, alternatively, it is a decrease in the value of money. Inflation is one of those macroeconomic variables that affect every Indian citizen, irrespective of an investor, borrower or lender, almost every day. Inflation is seen as negative news by the stock markets, because it tends to curb consumer spending and therefore corporate profits. It also affects the value of the domestic currency adversely in the foreign exchange markets. The two frequently used measures of inflation in India are based on the WPI and the Consumer Price Index (CPI). Unfortunately, in India we do not have an aggregate CPI appropriate for use as an indicator of aggregate prices and demand pressures. Thus in this study WPI is used as a proxy to Indian domestic inflation. The WPI is available for all commodities, and for major groups, sub-groups and individual commodities. The basic advantage of this measure of inflation is its availability at high frequency, i.e., on weekly basis with a gap of about two weeks, thereby enabling continuous monitoring of the price situation for framing policies.

\subsubsection{Index of Industrial Production (IIP)}

A measure of real output or real economic activity often used is Gross domestic Product (GDP) or Index of Industrial Production (IIP) (Birajdar et al., 2007). Since, this study is based on monthly data and due to the availability of only quarterly, half yearly and yearly GDP data, IIP is chosen as a measure of real output and a proxy to GDP. This IIP is the general IIP computed as the weighted average of all use based IIP, by the Ministry of Statistics and Programme Implementation, Government of India. As IIP numbers present a measure of overall economic activity in the economy and affect stock prices through its influence on expected future cash flows there exists a positive relationship between stock prices and IIP.

\subsubsection{Exchange Rate (i.e., INRUS\$)}

The other important macroeconomic variable used in this study has been the exchange rate, which represents the bilateral nominal rate of exchange of the Indian Rupee (Rs.) against one unit of a foreign currency namely US Dollar (\$) has been taken to be the foreign currency against which the Indian Rupee exchange rate is considered. This is because the US Dollar has remained to be the most dominating foreign currency used for trading and investment throughout the period of this study. On an average, export-oriented companies are adversely affected by a stronger domestic currency while import-oriented firms benefit from it.

\subsubsection{Call Money Rate (CMR)}

The overnight call money or the inter-bank money market rate is presumably the most closely watched variable in day-to-day conduct of monetary operations and often serves as an operating

target for policy purposes. The observations in regard to the relationship between interest rates and stock prices generally suggests that an increase in interest rates increases the opportunity cost of holding money and thereby causing substitution of stocks with interest bearing securities, and hence would result in falling stock prices. This rate is fully market-driven and dependent on the demand-supply equilibrium relationships. Changes in the CMR affect the Indian stock markets by affecting the corporate profits, general demand for goods and services in the economy, relative attractiveness of competing financial assets like shares, bonds, and other fixed-interest investments, the way companies finance their operations and cost of borrowing money for the purchase of shares.

\subsubsection{Foreign Institutional Investments (FII)}

In this age of transnational capitalism, countries and firms are interested in attracting foreign capital because it helps to create liquidity for the firms and the stock market in general. A significant amount of capital is invested into developing economies from developed world. Significant amount of these investment are bought to developing economies by the way of portfolio investments by foreign institutional investors (FII). Foreign institutional investors have gained a significant role in Indian capital markets. Availability of foreign capital depends on many firm specific factors other than economic development of the country.

\subsubsection{Money Supply}

Money supply is another fundamental macroeconomic variable which widely used in the literature to determine the stock prices. Beside the extensive empirical investigation, the relationship between money supply and stock price is still ambiguous. According to the portfolio theory, an increase in the money supply may results in a portfolio change from noninterest bearing money assets to financial assets like stock.

\subsection{Research Methodology}

The present study employs the time series data analysis to study the relationship between Indian stock market and macroeconomic variables taken for study. The data series must obey the time series properties i.e., time series data should be stationary meaning the mean and variance should be constant over a period of time. 


\subsubsection{Stationary Tests}

Empirical research in stock markets is based on time series data. stationarity of a data series is a prerequisite for drawing meaningful inferences in a time series analysis and to enhance the accuracy and reliability of the models constructed. Generally a data series is called a stationary series if its mean and variance are constant over a given period of time and the covariance between the two extreme time periods does not depend on the actual time at which it is computed but it depends only on lag amidst the two extreme time periods. In this study the test of stationarity of the time series data of the above mentioned variables have been systematically done in order to rule out the likely spurious results. Augmented Dickey-Fuller test (ADF) is a test for a unit root in a time series sample. It is an augmented version of the Dickey-Fuller test for a larger and more complicated set of time series models and is applied as follows,

$$
\Delta y_{t}=\alpha+\beta t+\gamma y_{t-1}+\delta_{1} \Delta y_{t-1}+\cdots+\delta_{p-1} \Delta y_{t-p+1}+\varepsilon_{t}
$$

where $\alpha$ is a constant, $\beta$ the coefficient on a time trend and $p$ the lag order of the autoregressive process. Imposing the constraints $\alpha=0$ and $\beta=0$ corresponds to modeling a random walk and using the constraint $\beta=0$ corresponds to modeling a random walk with a drift.

\subsubsection{Descriptive Statistics}

It describes the main features of collection of data. In this study descriptive statistics is computed with mean, median, standard deviation, skewness, kurtosis and Jarque Bera tests for the selected economic variables

\subsubsection{Granger Causality Test}

The Granger causality test as proposed by C. J. Granger in 1969 establishes short-run relationships between stock prices and macroeconomic variables. It enables us to identify leading, lagging and coincidence microeconomic and macroeconomic variables for the stock market's performance It also used as a measures the precedence and information content but does not itself has causality in the more common use of the term. If the computed $F$-value exceeds the critical $F$-value at the chosen level of significance, the null hypothesis is rejected. This would imply that macroeconomic variable 'Granger cause' or improve the prediction in stock prices and vice versa. Under the Granger causality test, the null hypothesis is $\Sigma \alpha i=0$ for all values of $i$. To test this F-test is used. If the computed $F$-value exceeds the critical $F$-value at the chosen level of significance, the null hypothesis is rejected. This would imply that macroeconomic variable 'Granger cause' or improve the prediction in stock prices and vice versa.

\section{Empirical Results and Discussions}

\subsection{Descriptive Statistics Results}

Table 1:DescriptiveStatistics

\begin{tabular}{|l|l|l|l|l|l|l|l|}
\hline Statistics & $\begin{array}{l}\text { BSE } \\
\text { SENSEX }\end{array}$ & CMR & $\begin{array}{l}\text { EXCHANGE } \\
\text { RATE }\end{array}$ & FII & IIP & $\begin{array}{l}\text { MONEY } \\
\text { SUPPLY }\end{array}$ & WPI \\
\hline Mean & 16089.63 & 6.512386 & 47.06328 & 7212.025 & 136.3148 & 5422935 & 137.6580 \\
\hline Median & 17035.74 & 6.935000 & 46.22340 & 5341.650 & 135.0000 & 5202439 & 132.9000 \\
\hline Maximum & 20509.09 & 12.41000 & 59.43200 & 35227.90 & 168.6000 & 8745410 & 175.4000 \\
\hline Minimum & 8891.610 & 0.170000 & 32.79250 & -17205.40 & 108.0000 & 2775005 & 107.6000 \\
\hline Std. Dev & 3060.784 & 2.211875 & 4.968070 & 10904.48 & 14.39065 & 1791791 & 20.48164 \\
\hline Skewness & -0.742602 & -0.178229 & 0.222126 & 0.459842 & 0.031684 & 0.190916 & 0.306018 \\
\hline Kurtosis & 2.639527 & 3.221559 & 3.025484 & 2.739831 & 2.257185 & 1.812134 & 1.744260 \\
\hline Jarque-Bera & 8.564492 & 0.645887 & 0.726033 & 3.349526 & 2.257185 & 5.708341 & 7.155394 \\
\hline Probability & 0.013812 & 0.724015 & 0.695575 & 0.187353 & 0.323488 & 0.057604 & 0.027940 \\
\hline Observations & 88 & 88 & 88 & 88 & 88 & 88 & 88 \\
\hline
\end{tabular}

The above table 1 represents the summary statistics of the variable sunder study. The average monthly index of BSE Sensex is 16089.63 during the study period from April 2006 to July 2013 with a high standard deviation (i.e 3060.784) implying a volatile stock market. The average inflation represented by whole sale price index is $137.6580 \%$ with maximum of $175.4000 \%$ and minimum of $132.9000 \%$. This indicates pressure on purchasing power of the general public and less amount of liquidity as available to the investors to invest in the Indian Stock market, The average INR/USD exchange rate is Rs.47.06328/USD with a maximum of Rs.59.43200/USD and a minimum of Rs.32.79250, the exchange rate is also quite volatile with standard deviation of 4.968070 during the study period. The average interest rate represented by call money rate is $6.512386 \%$ during the study period with 2.211875. But recent trend is declining as the Government of India has undertaken the necessary steps to reduce the interest rate in order to encourage the investors to invest in the Indian Stock market.

The value of skewness for the variables chosen for study in the above table has pointed out that for the two variables namely BSE Sensex (-0.742602) and call money rate (-0.178229) is negatively skewed meaning 
the mean of the observation is less than the median and for all other variables it is positively skewed and indicates a deviation from normal distribution of the data and volatility in those parameters. The value of kurtosis has pointed for the variables call money rate (3.221559) and Exchange rate (3.025484) had leptokurtic distribution (i.e., >3) with the values concentrated around the mean and thicker tails. This means high probability for extreme values which is observed from the above table.. The kurtosis value of all other variables like BSE sensex (0.013812),Foreign Institutional Investment (2.739831) Industrial Productivity (2.257185), money supply (1.812134), whole sale price index (1.744260) indicates platykurtic distribution(i.e., <3) and the values are wide spread around the mean. Jarque Bera test statistic measures the difference of the skewness and kurtosis of the data series from the normal distribution. The results from the above table show that the data do not support the supposition that each variable has a normal distribution.

Table 2:Augmented Dickey Fuller Test

\begin{tabular}{|l|c|c|c|c|}
\hline \multicolumn{1}{|c|}{ Variables } & Level & $\mathrm{I}^{\mathrm{st}}$ Difference & $\mathrm{II}^{\text {nd }}$ Difference & Order of Integration \\
\hline BSE Sensex & $\begin{array}{c}-2.263937 \\
{[-3.462292]}\end{array}$ & $\begin{array}{c}-9.042395 \\
{[-4.068290]}\end{array}$ & - & $\mathrm{I}(1)$ \\
\hline \multirow{2}{*}{ CMR } & $\begin{array}{c}-3.289814 \\
{[-3.462912]}\end{array}$ & $\begin{array}{c}-8.770382 \\
{[-4.071006]}\end{array}$ & - & $\mathrm{I}(1)$ \\
\hline Exchange Rate & $\begin{array}{c}-1.894890 \\
{[-3.462292]}\end{array}$ & $\begin{array}{c}-10.06048 \\
{[-3.462912]}\end{array}$ & - & $\mathrm{I}(1)$ \\
\hline \multirow{2}{*}{ FII } & $\begin{array}{c}-6.808223 \\
{[-3.462292]}\end{array}$ & - & - & $\mathrm{I}(0)$ \\
\hline \multirow{2}{*}{ IIP } & -0.664696 & -3.304431 & -8.712213 & $\mathrm{I}(2)$ \\
\hline \multirow{2}{*}{ Money Supply } & $\begin{array}{c}-2.393002] \\
{[-3.462292]}\end{array}$ & $\begin{array}{c}-11.80386 \\
{[-3.462912]}\end{array}$ & - & $\mathrm{I}(1)$ \\
\hline \multirow{2}{*}{ WPI } & -2.154226 & -4.210301 & -11.87576 & $\mathrm{I}(2)$ \\
\hline
\end{tabular}

The stationarity of the data series has been established by the standard procedure of unit root by employing Augmented Dickey Fuller (ADF) test. On the basis of the test results, the series are found to be nonstationary except for Foreign Institutional Investment at level with trend and intercept. However after taking the first difference these variables are found to be stationary at 5 percent level. Thus the variables BSE Sensex, Call money rate, exchange rate, money supply are individually integrated of the order I(1), Foreign institutional investment was integrated of the order $\mathrm{I}(0)$ whereas Industrial Productivity and Wholesale price index was integrated of the order I(2).

Table 3: Pair wise Pearson coefficient of Correlation

\begin{tabular}{llllllll}
\hline & $\begin{array}{l}\text { BSE } \\
\text { Sensex }\end{array}$ & CMR & $\begin{array}{l}\text { Exchange } \\
\text { Rate }\end{array}$ & FII & IIP & $\begin{array}{l}\text { Money } \\
\text { Supply }\end{array}$ & WPI \\
\hline BSE Sensex & 1.000000 & & & & & & \\
CMR & 0.208391 & 1.000000 & & & & & \\
Exchange Rate & 0.123505 & 0.197992 & 1.000000 & & & & \\
FII & 0.455843 & -0.133858 & 0.257149 & 1.000000 & & & \\
IIP & 0.643759 & 0.301254 & 0.577919 & 0.311640 & 1.000000 & & \\
Money Supply & 0.634823 & 0.276535 & 0.754224 & 0.361876 & 0.909061 & 1.000000 & \\
WPI & 0.63310 & 0.354680 & 0.744525 & 0.338387 & 0.895449 & 0.992051 & 1.000000 \\
\hline
\end{tabular}

It can be clearly seen that the correlations among the variables under study is positive and varies from low to high. It may be seen as first indication for the existence of interdependency among them. The highest of correlation is between whole sale price index and money supply (over 99\%) and the next highest order is between money supply and Industrial Productivity (over 91\%)BSE Sensex is relatively lesser correlated with exchange rate(over 12\%).However the correlations need to be verified by the Granger causality test.

Table 4: Granger Causality Test

\begin{tabular}{lcrr} 
Null Hypothesis: & Obs & F-Statistic & Prob. \\
\hline \hline CMR does not Granger Cause BSE_SENSEX & 86 & 1.90707 & 0.1551 \\
BSE_SENSEX does not Granger Cause CMR & & 2.54252 & 0.0849 \\
\hline \hline EX_RATE does not Granger Cause BSE_SENSEX & 86 & 1.12061 & 0.3311 \\
BSE_SENSEX does not Granger Cause EX_RATE & 0.36582 & 0.6948 \\
\hline \hline FII does not Granger Cause BSE_SENSEX & 86 & 3.56261 & $0.0329^{*}$ \\
BSE_SENSEX does not Granger Cause FII & & 0.26163 & 0.7704 \\
\hline \hline
\end{tabular}


Indian Stock market and Aggregate macroeconomic variables: Time Series Analysis

\begin{tabular}{|c|c|c|c|}
\hline $\begin{array}{l}\text { IIP does not Granger Cause BSE_SENSEX } \\
\text { BSE_SENSEX does not Granger Cause IIP }\end{array}$ & 86 & $\begin{array}{l}0.80274 \\
2.06006 \\
\end{array}$ & $\begin{array}{l}0.4516 \\
0.1341 \\
\end{array}$ \\
\hline $\begin{array}{l}\text { MONEY_SUPPLY does not Granger Cause BSE_SENSEX } \\
\text { BSE_SENSEX does not Granger Cause MONEY_SUPPLY }\end{array}$ & 86 & $\begin{array}{l}0.94025 \\
0.75470\end{array}$ & $\begin{array}{l}0.3948 \\
0.4734\end{array}$ \\
\hline $\begin{array}{l}\text { WPI does not Granger Cause BSE_SENSEX } \\
\text { BSE_SENSEX does not Granger Cause WPI }\end{array}$ & 86 & $\begin{array}{l}0.97261 \\
3.51272\end{array}$ & $\begin{array}{r}0.3825 \\
0.0344^{*}\end{array}$ \\
\hline $\begin{array}{l}\text { EX_RATE does not Granger Cause CMR } \\
\text { CMR does not Granger Cause EX_RATE }\end{array}$ & 86 & $\begin{array}{l}0.42834 \\
0.97455\end{array}$ & $\begin{array}{l}0.6531 \\
0.3817\end{array}$ \\
\hline $\begin{array}{l}\text { FII does not Granger Cause CMR } \\
\text { CMR does not Granger Cause FII }\end{array}$ & 86 & $\begin{array}{l}1.07730 \\
0.14827\end{array}$ & $\begin{array}{l}0.3453 \\
0.8624\end{array}$ \\
\hline $\begin{array}{l}\text { IIP does not Granger Cause CMR } \\
\text { CMR does not Granger Cause IIP }\end{array}$ & 86 & $\begin{array}{l}0.53517 \\
0.25595\end{array}$ & $\begin{array}{l}0.5876 \\
0.7748\end{array}$ \\
\hline $\begin{array}{l}\text { MONEY_SUPPLY does not Granger Cause CMR } \\
\text { CMR does not Granger Cause MONEY_SUPPLY }\end{array}$ & 86 & $\begin{array}{l}0.81865 \\
0.02252\end{array}$ & $\begin{array}{l}0.4446 \\
0.9777 \\
\end{array}$ \\
\hline $\begin{array}{l}\text { WPI does not Granger Cause CMR } \\
\text { CMR does not Granger Cause WPI }\end{array}$ & 86 & $\begin{array}{l}1.17997 \\
3.11960\end{array}$ & $\begin{array}{r}0.3125 \\
0.0495^{*} \\
\end{array}$ \\
\hline $\begin{array}{l}\text { FII does not Granger Cause EX_RATE } \\
\text { EX_RATE does not Granger Cause FII }\end{array}$ & 86 & $\begin{array}{l}1.22813 \\
4.85099\end{array}$ & $\begin{array}{r}0.2982 \\
0.0102 *\end{array}$ \\
\hline $\begin{array}{l}\text { IIP does not Granger Cause EX_RATE } \\
\text { EX_RATE does not Granger Cause IIP }\end{array}$ & 86 & $\begin{array}{l}1.74086 \\
1.38748\end{array}$ & $\begin{array}{l}0.1819 \\
0.2556\end{array}$ \\
\hline $\begin{array}{l}\text { MONEY_SUPPLY does not Granger Cause EX_RATE } \\
\text { EX_RATE does not Granger Cause MONEY_SUPPLY }\end{array}$ & 86 & $\begin{array}{l}2.88212 \\
0.49370\end{array}$ & $\begin{array}{l}0.0618 \\
0.6122 \\
\end{array}$ \\
\hline $\begin{array}{l}\text { WPI does not Granger Cause EX_RATE } \\
\text { EX_RATE does not Granger Cause WPI } \\
\end{array}$ & 86 & $\begin{array}{l}5.31564 \\
1.12452\end{array}$ & $\begin{array}{r}0.0068^{*} \\
0.3298 \\
\end{array}$ \\
\hline $\begin{array}{l}\text { IIP does not Granger Cause FII } \\
\text { FII does not Granger Cause IIP }\end{array}$ & 86 & $\begin{array}{l}1.33350 \\
2.53251\end{array}$ & $\begin{array}{l}0.2693 \\
0.0857\end{array}$ \\
\hline $\begin{array}{l}\text { MONEY_SUPPLY does not Granger Cause FII } \\
\text { FII does not Granger Cause MONEY_SUPPLY }\end{array}$ & 86 & $\begin{array}{l}2.53921 \\
0.69963\end{array}$ & $\begin{array}{l}0.0852 \\
0.4997 \\
\end{array}$ \\
\hline $\begin{array}{l}\text { WPI does not Granger Cause FII } \\
\text { FII does not Granger Cause WPI }\end{array}$ & 86 & $\begin{array}{l}1.77242 \\
0.54123\end{array}$ & $\begin{array}{l}0.1764 \\
0.5841\end{array}$ \\
\hline $\begin{array}{l}\text { MONEY_SUPPLY does not Granger Cause IIP } \\
\text { IIP does not Granger Cause MONEY_SUPPLY }\end{array}$ & 86 & $\begin{array}{l}2.94606 \\
2.62531\end{array}$ & $\begin{array}{r}0.0582 * \\
0.0786\end{array}$ \\
\hline $\begin{array}{l}\text { WPI does not Granger Cause IIP } \\
\text { IIP does not Granger Cause WPI }\end{array}$ & 86 & $\begin{array}{l}7.21050 \\
8.39106\end{array}$ & $\begin{array}{l}0.0013^{*} \\
0.0005^{*}\end{array}$ \\
\hline $\begin{array}{l}\text { WPI does not Granger Cause MONEY_SUPPLY } \\
\text { MONEY_SUPPLY does not Granger Cause WPI }\end{array}$ & 86 & $\begin{array}{l}2.28019 \\
5.20043\end{array}$ & $\begin{aligned} 0.1088 \\
0.0075^{*}\end{aligned}$ \\
\hline
\end{tabular}

*Null hypothesis rejected at 5\% significance level

The Granger Causality is conducted to study the causal relationship between macro economic variables and the Indian stock market. Table 4 reported pair wise granger causality test results with lags 2 as two lag is an appropriate lag order chosen in terms of Akaike Information Criteria (AIC) for the sample period.BSE Sensex, Call money rate, Exchange rate between Indian rupees and US dollar, Foreign institutional Investment Industrial Productivity, money supply and whole sale price index are found to be the most important variable in determining stock market return. The reported F-values suggests that there is unidirectional causality between Foreign institutional Investment and BSE Sensex, BSE Sensex and Whole sale Price Index, Call Money rate and Whole Sale Price Index, Whole Sale Price Index and Exchange Rate, Money Supply and Industrial Productivity Money Supply and Whole sale price index. It is also found from the above table that there is bidirectional relationship between whole sale price index and Industrial productivity. So it suggests that whole sale price index and industrial productivity are influencing the stock market and also any change in stock market is also influenced by whole sale price index and industrial productivity. Again it is observed from the table---- there is no apparent causality between call money rate and BSE Sensex, Exchange rate and BSE Sensex, Exchange rate and call money rate, Industrial productivity and foreign institutional investment.

\section{Conclusion}

This study examines the relationship between the stock market as proxied by BSE Sensex and a set of macroeconomic variables during the period April 2006 to July 2013.It is observed that in the long run, the stock prices are positively related to interest rate as proxied by call money rate and real economic activity represented by industrial productivity. The whole sale price index has found to be negatively related to BSE Sensex. The exchange rate between Indian Rupees and US Dollar is also turning out to be a negatively significant 
determinant of Indian stock market. Given the demand for money, there is a direct inverse relationship between money supply and interest rate. Probably, stock market reacts to money supply only if it causes changes in interest rate. This study has found no significant relationship between BSE Sensex and the macro economic variables selected by applying Granger causality test. This inference itself act as a limitation for this study because variables such as exchange rate, Foreign Institutional Investment, money supply with general public would have some sort of influence and impact on Indian stock market and its indices. Also selection of some variables such as WPI, CMR, IIP would not be free from subjective biases. WPI's limitation lies in excluding prices of retail and other services that are part of the hypothetical average consumer, domestic interest rate has many proxy representatives to be used in the place of CMR such as 90 days Treasury Bills.Many variables taken for study such as interest rate, inflation, exchange rate, flow of foreign institutional investment are also dependent on some global macro economic factors, situations and events. The present study confirms that macro economic factors continue to affect Indian stock market.

\section{References}

[1] Abdalla, I. S. A. and V. Murinde (1997), "Exchange Rate and Stock Price Interactions in Emerging Financial Markets: Evidence on India, Korea, Pakistan, and Philippines," Applied Financial Economics 7, 25-35.

[2] Ashima Goyal 2011,"History of monetary policy since independence", Indira Gandhi Institute of Development Research, Mumbai, WP-2011-018, September 2011.

[3] Bhattacharya, B. and J. Mukherjee (2003), "Causal Relationship between Stock Market and Exchange Rate. Foreign Exchange Reserves and Value of Trade Balance: A Case Study for India", The 5th Annual Conference on Money and Finance in the Indian Economy on January 2003

[4] Bhattacharyya, B., Mukherjee, J. 2006. Indian Stock Price Movement and the Macroeconomic context - A Time Series Analysis. Journal of International Business and Economics 5:1, 167-181.

[5] Bahmani-Oskooee, M. and A. Sohrabian (1992), "Stock Prices and the Effective Exchange Rate of the Dollar" Applied Economics 24, pp:459-464.

[6] Gay, R.D. Jr., 2008. "Effect of Macroeconomic Variables on Stock Market Returns for Four Emerging Economies: Brazil, Russia, India, And China", International finance and economic Journal.

[7] Girisha M C 2012, "India and Foreign Institutional Investors" IOSR Journal of Business and Management, Vol:5, Issue I Sep to Oct, pp:01-04.

[8] Himanshu Joshi 2004, "The Interbank money market in India: Evidence on volatility, efficacy of regulatory initiatives and implications for interest rate targeting" Reserve Bank of India Occasional papers Vol.25, No.1,2 and 3, Summer, Monsoon and Winter

[9] Ma, C. K. and G. W. Kao 1990, On Exchange Rate Changes and Stock Price Reactions, Journal of Business Finance and Accounting, 17, 441-449.

[10] Naliniprava Tripathy, 2011, "Causal Relationship between Macro-Economic Indicators and Stock Market in India", Asian Journal of Finance \& Accounting, Vol. 3, Issue No. 1, pp: 207-226.

[11] Nucu, Anca, E. (2011). The Relationship between Exchange Rate and Key Macroeconomic Indicators. Case Study: Romania. Romanian Economic Journal, 41, pp: 127-145.

[12] Pethe, A., Karnik, A., 2000. "Do Indian Stock Markets Matter? - Stock Market Indices and Macro-economic Variables", Economic and Political Weekly 35:5, pp. 349-356.

[13] Pramod Kumar Naik, 2013, "Does stock market respond to Economic Fundamentals? Time series analysis from Indian data. Journal of applied Economics and Business Research, Vol:3, Issue:1,pp:34-50.

[14] Rahman, M.L. \& Uddin, J. (2009). Dynamic Relationship between Stock Prices and Exchange Rates: Evidence from Three South Asian Countries. International Business Research, 2, pp:167-174.

[15] Ranjan Dasgupta 2012, "Long run and short run relationships between BSE sensex and macroeconomic variables" International Research Journal of Finance and Economics, Issue:95, pp:135-160

[16] Shahid Ahmed, 2008, "Aggregate Economic variables and Stock markets in India", International Research Journal of Finance and Economics, Issue 14, pp: 141-164

[17] Wongbampo, P., Sharma, S.C. 2002. Stock Market and Macroeconomic Fundamental Dynamic Interactions: ASEAN-5 Countries. Journal of Asian Economics 13, 27-51.

[18] Yadav, I.S., Lagesh, M.A., 2011. "Macroeconomic Relationship in India: ARDL Evidence on Cointegration and Causality", Journal of Quantitative Economics 9:1, pp. 156-168. 